Yet the tension continues. Successful as it is, the waterfall is not left running all the time because when it is on, the bridge cannot be used. Art and utility impossible to have both. It is turned on for special occasions: the first of July, the opening of city festivities. This ironic manipulation of an imitation of nature is a clear example of the trickster in Canadian art and artists. What is real: a natural waterfall, this waterfall when it is turned on or this waterfall when it is turned off? Or no waterfall at all? That bridge waterfall is, I think, the best metaphor for Canada's transition between the indigenous and the metropolitan. That artist accomplished without words a statement on our position bestride the two. We come out of an overwhelming landscape and wilderness which we want to retain, yet we are determined to be metropolitan. Art can meld the two; the tension between them gives Canadian art its force and continues to strengthen us. We are all dreaming waterfalls that shimmer from civilized bridges. We are all writing them.

University of Calgary, Canada

\title{
General and Comparative
}

\section{Eurocentrism and Criticism: Reflections on the Study of Literature in Past and Present World Literature Written in English, Volume 24, No. 1 (1984), 16-27.}

\section{MINEKE SCHIPPER}

The conflict between historical relativism and perspectivism in the study of literature has been a subject of discussion for many years. Historical relativism stems from historicism - an approach that sees everything in purely historical terms, unrelated to the political context, ethics or religion. The past was important as past, in the belief that it was possible to reconstruct this past exactly as it had been. The point of perspectivism, in the words of René Wellek, is "that we recognize that there is one poetry, one literature comparable in all ages." Wellek is sharply opposed to relativism, which he equates with an "anarchy of values." I It is significant to note that this discussion took place at a relatively late stage - starting in the 1950 s and gaining momentum in the sixties and the years that followed. 2

The term cultural relativism was used in connection with the study of literature for the first time in 1969 by Roy Harvey Pearce in a footnote to an article in his Historicism Once More. The Dutch comparatist D.W. Fokkema 
expanded on this in a 1971 lecture on cultural relativism and comparative literature. He defined cultural relativism in the study of literature as the approach that interprets the literary-historical phenomena of a given period within the context of a particular cultural area. This approach makes its assessment on the basis of the norms and against the background of both the period and the cultural area, and then compares with each other the various value systems that characterize the different periods and cultural areas. ${ }^{3}$ In my opinion, to period and cultural area one must add the social group from which the particular literature has originated and by whom it is read. The latter has often been forgotten or neglected.

Scientific research has been enriched in a number of fields as a result of Western imperialism and colonialism: anthropology, one of the first human sciences, profited enormously. Perhaps this is the reason that developments took place at such an early stage in anthropology which only much later manifested themselves in the area of literary studies. The problem of cultural relativism can be clearly distinguished in these developments, and for this reason I now propose we make a brief detour to anthropology. The fact that oral literature was for a such a long time seen as a province of anthropology and was studied primarily by this discipline has not always been beneficial to its literary aspects. Of course, scholars and students of literature are partly to be blamed for this.

The anthropologists went through phases of evolutionism and cultural relativism. E.B. Tylor preached evolutionism in his Primitive Culture (1871). His views were clearly Eurocentric: modern Western civilization was his norm - all non-Western peoples were "less advanced." According to Tylor, they had stayed behind in an earlier stage. For him and his followers, there was a single process of evolution that encompassed all of nature and culture.

Franz Boas later opposed this in, among others, The Mind of Primitive Man (1911) and Race, Language and Culture (1940). He criticized evolutionism because it claimed to be able to reconstruct a history of culture that applied to the whole human race. Just after the turn of the century, Boas was already warning his students against projecting their own Western values and categories on the cultures they wanted to study. This brought enormous changes. The word "culture," for example, was given a plural form for the first time. People reached the conclusion that there was a nearly infinite number and variety of cultural elements.

For Tylor, the evolutionists and all who preceded them, culture had always meant enlightenment and progress, resulting from rationality and creativity. After Boas, however, it began more and more to take on the opposite meaning: culture as that which binds people to tradition, to the irrational. Man is no longer seen as the creator of culture but rather as the creation of his own culture. Familiar names from the Boas school are Ruth Benedict and Melville Herskovits: they stressed the equal value of all cultures. According to Herskovits, there is actually no one who is qualified to make judgements about aspects of another culture or about other cultures as wholes. Why?

Herskovits said that these value judgements depend on one's own cultural 
experience and are no more than reflections of one's own culture and its prejudices, since one assumes one's own categories to be generally valid. One is thus forced to conclude that no general judgements are possible. A culture can only be assessed by someone who is a carrier of that same culture. Unfortunately, here one is losing one's vision of the whole. In fact, what Herskovits wants is for Western scientists to overcome their ethnocentrism and take a tolerant view of all other cultures: a peaceful co-existence on the basis of cultural relativism rather than ethnocentrism. Whereas ethical imperialism had led to missionaries and colonialism, ethical relativism led to anti-missionarism, anti-colonialism and anti-imperialism. Similar developments also took place in such fields as sociology and history. New definitions had to be formulated and new words coined because the point of departure had changed. Pizarro, Stanley and Cook, for example, could no longer be termed "explorers"; the phrase "voyage of discovery" could no longer be used.

On the surface, cultural relativism might seem very appealing, but the difficulty is the idea of objectivity, the denial of value judgements: on the one hand, Herskovits denies that it is possible for human beings to make valuefree, non-culture-bound judgements; on the other hand, he wants to practise an anthropology that is objective, value free and not bound by culture. We can see a definite contradiction here. 4 In fact, cultural relativism actually confirms ethnocentrism. The democratic idea of cultural relativism is that everyone is ethnocentric. One is preaching for the status quo, assuming an immutability of real differences between cultures and adamantly opposing the contamination of one culture with elements from another. Emphasis comes to lie on isolation, a sort of apartheid that is, unfortunately, familiar to us from the South African context: people are trapped in the straight-jacket of cultural determinism. Actually, cultural relativism is nothing more than a theoretical protest against the centuries-long process of Westernizing the human race. Historically, it is interesting to note how much the field of anthropology actually served colonialism.

Tylor's theory, the anthropology of evolutionism, justified colonialism "bringing civilization to the natives." 5 During the next stage, when the West thought that not too much civilization should be brought to the "natives" because it might make them troublesome, the theory of cultural relativism was very handy. It justified conservatism: existing cultures had to be respected (and inequalities perpetuated). Nonetheless, the insight into the inevitability of ethnocentrism can be useful, not only for anthropologists, but also for scholars in other fields: value systems from various cultures should be the subject of comparative research.

Especially after the world wars, and as a result of the start of decolonization, historians also began to realize that a new approach to history and a new historiography were needed. Arnold Toynbee was one of the bestknown proponents of this in Europe. In his essay, "Widening Our Historical Horizon," he noted that historians can have a great deal of political influence:

History tells us that historians, like scientists, do have an impact on society, 
and if the historian is a teacher, his impact is direct and immediate. Nineteenth-century historians . . . stoked up the fires of nationalism, and the consequence is that these fires are still raging today, when we have been carried by the scientists into the Atomic Age ... The historian has a practical responsibility ... The student and writer and teacher of history ought to strive now, with all his might, to widen his public's historical horizon; and to do this, he must begin by widening his own. 6

Developments that have taken place in anthropology and in history indicate that a growing number of scholars have begun to take a critical look at the forms of ethnocentrism - or more properly Eurocentrism - and at the implicated value systems in their own disciplines.

What does all of this have to do with literature? Have we put evolutionist thinking behind us in our discipline as the anthropologists have? Are we, like the historians, interested in new definitions and perspectives in literary studies? What about the social relevance of our research - do we have the practical responsibility Toynbee spoke of? In anthropology and non-Western sociology (a Eurocentric term, by the way), the shift came because of intensive field research outside Europe at a comparatively early stage and, later, through the inevitable confrontation between Western researchers and their Asian, Latin American and African colleagues. As I mentioned before, the literature of other cultures has long been considered a logical component of anthropological and sociological studies.

Why then, with the exception of writers such as Ruth Finnegan, has oral literature so seldom been seen as a research topic for students of literature? 7 Have the echoes of decolonization not reverberated through to literary discussions? If so, what of this has been passed on to literary research, criticism and education? I think that the combination of analysis and qualitative evaluation that characterizes so much of the Western critical tradition has played a part. But we need not be pessimistic.

The theoretical component of comparative literature study has only recently been set down in statutory terms in the International Comparative Literature Association. Comparative literature study is defined in this 1979 document as "the study of literary history, the theory of literature and the interpretation of texts, undertaken from an international point of view."

Without taking the time to go more deeply into the historical developments, suffice it to say that new approaches to literature leave ample room for the comparative study of literature from various cultures, whether this involves relationships of contact (influences, for example,) or of typological similarities (genre characteristics, for instance). Profiting from developments in semiotics, the study of literature has begun to liberate itself from the old approach with its inflexible, Western norms and values that characterized so many researchers for so long.

Many now direct their attention to the literary communication situation and to the conventions of the production and reception of texts that are accepted as literary under certain social, cultural and political circumstances. A distinction, as strict as possible, is now made between the reader and the 
researcher, between the historical reception of certain texts and one's own evaluation. Unlike New Criticism and its British variation, practical criticism, the scientific study of literature aims neither at the transfer of literary values, nor at the creation or the defence of a literary tradition. Within the new study of literature, the transfer of literary values and the formation of literary traditions are, on the contrary, the object of research. 8

The developments that have led to a new vision of the scientific relevance of the field are extremely encouraging. They inevitably lead to the awareness of one's ethnocentrism, (i.e. Eurocentrism) as far as the study of literature is concerned. This awareness enables the researcher to adopt a critical attitude, especially an autocritical attitude, and to reflect upon the social interests and the cultural, social and historical values of the group he belongs to. Such an attitude may help him to overcome his own ideology in studying literature. 9

The theory, however, often bears little resemblance to most of the practice of research, criticism and education. Literary criticism in particular is clearly dominated by institutionalized literature and its associate value system in a given society. This leads to an attitude of exclusiveness which will make the critics refuse to look at any text which does not correspond to their established criteria. A plea for a more inclusive attitude (more openness towards literatures from other cultures) is not out of place in such a case.

Literature has for too long been a given institution, especially in the Western world; it has been accepted for a long time that most of what is called world literature is necessarily Western literature. That literature is an institution is clear if one looks at the textbooks and anthologies used in schools. Pupils are exposed to these books and, in this way, an identification is created in their minds between what the book contains and what literature is or should be. Writers' names and texts or fragments of texts are included in the book because they are literary, and they are literary because they are in the book. The literature textbook involves a selection and thus presents a picture of what its editors think literature is in terms of the value system they hold. What is passed on in history as literature - national or international - seems to be the heritage for the new generation, but in fact it is a heritage of which a large part has been held back and is never referred to.

An interesting study by Bernard Mouralis, Les Contre-Littératures, refers to this concealed part as the field of counter-literatures, which tries in many ways to attract the attention of that small, élite group who decides what may or may not be counted as literature. The counter-literatures include both oral and written works from the present and the past. Nowadays, one must also include popular magazines, comic strips, science fiction, detective stories and romances. In the Western vision of what is literature, the vast majority of works from other cultures also belong to this large field of counter-literatures. Nevertheless, from a historical point of view, shifts are taking place in the evaluation and assembly of a literary heritage. In his above-mentioned book, Mouralis offers a brief summary of the changes in Western Europe, especially France: after classicism, the supremacy of the classic heritage was disputed - in France with the appearance of the Querelle des Anciens et des Modernes. The 
cultural horizon was expanded through acquaintance with other ancient civilizations (for example, Egypt and the Middle East) or modern ones (like Persia, China and the United States). After this, more attention was also given in the West to the literature from other European countries and to one's own folk literature. In the nineteenth century, new literatures in European languages such as English, Spanish and Portuguese were discovered in other parts of the world. These became further and further removed from the exclusive European influence. Thanks to anthropological research, twentiethcentury Westerners came into contact with the oral literature of Africa, the United States and Oceania. Recently, there is also a large supply of literatures that stem from colonial, semi-colonial and post-colonial societies and sharply oppose Western cultural domination. One must add to this that the immigration of large groups of people with other cultures, and their permanent settlement in the Western world, is certainly influencing or will influence the literature and culture of this part of the world.10

In a number of ways, the counter-literature mechanism, as it has been described by Mouralis, can be compared with the polysystem theory of Itamar Even-Zohar. This theory (which is applicable not only to the study of literature) sees the sign-governed human patterns of communication (culture, language, literature, society) as systems of a heterogeneous, open structure:

It is, therefore, very rarely a uni-system but is necessarily, a polysystem - a multiple system, a system of various systems which intersect with each other and partly overlap, using concurrently different options, yet functioning as one structured whole whose members are interdependent ...

The heterogenic structure of culture in society can, of course, be reduced to the culture of the ruling classes only ... but this would not be fruitful beyond the attempt to construct homogeneic models to account for the principal mechanisms governing a cultural system when time factor and adjacent systems' pressures are eliminated.11

He gives the example of a community possessing two literary options, two "literatures," because the society is bilingual, which has been or still is the case in many countries:

For students of literature, to overcome such cases by confining themselves to only one of these, ignoring the other, is naturally very "convenient" (or rather more "comfortable") than dealing with them both. Actually this is common practice in literary studies; how inadequate the results are cannot be exaggerated. 12

Of course, this is not only true for two literatures in different languages in one country, but also for the literatures of different social groups in the same country and for different literatures on the international and inter-cultural level as far as they influence each other in different ways within the "polysystem." One cannot consider one literature as a separate phenomenon, neglecting all the positive and negative relationships it has with other adjacent literatures. In the Western world, scholars have too often only considered and studied as 
literature the so-called masterpieces. Even-Zohar argues from a semiotic point of view against inflexible élitism, the equation of literary criticism with literary research and against writing the history of literature using only the writers of the masterpieces - who mostly represent only the culture of those who write this history of literature:

As scholars committed to the discovery of the mechanisms of literary history, we cannot use arbitrary and temporary value judgements as criteria in selecting the objects of study in a historical context. The prevalent value judgements of any period are themselves an integral part of the objects to be observed. No field of study can select its objects according to norms of taste without losing its status as an intersubjective discipline. 13

Only scant traces of the new trends and developments that have been summarized here can be recognized in the literary heritage that is passed on in the schools in literature education. What criteria are being used? Criteria of an esthetic and/or ethical nature? How is literature defined? With respect to the concept of literature, perhaps only one thing can be said with certainty - that people never seem to agree on how it should be defined. The formal criteria for what is to be considered as literature have shifted and been revised so many times in the course of Western history alone that it is impossible to see them as anything but arbitrary. The study of literature from other cultures makes the recognition of this arbitrariness all the more necessary.

It is for this reason that every encouragement should be given to the above view that study and evaluation should be separated from each other as much as possible in comparative literature. The continued use of inflexible standards of quality, as in Wellek's work, is inconsistent with this approach. Such an inflexible basis for study, in which Western literary values are seen as universal, has been sharply criticized in recent years outside Europe - criticism that is, in my opinion, largely justifiable. Until the 1960s, Western encyclopedia articles and textbooks on world literature were usually limited primarily to the description of Western literary works.

Such criticism from outside one's cultural context can be very enlightening: after all, anthropology benefited from Western anthropologists being confronted by the critical questions of scholars with other cultural backgrounds. Likewise, historians from Latin America, Asia and Africa have pointed to the one-sided, expansionist perspective from which Westerners tend(ed) to write history. Theological research has been given new impulses by the theologians of liberation from Latin America and by the black theology from North America and Africa.

To what extent can the same be said of the study of literature? I think that in our field the confrontations have been fairly recent. The transfer of Western literary values to other cultural contexts has been a fact of life for a long time. In the eyes of researchers from these cultures, this may have had some advantages, but it has also been damaging to their own cultures. Many discussions on this subject have taken place since the sixties and seventies, particularly in countries that have experienced Western colonialism. However, 
these discussions have seldom penetrated the walls of European schools and universities. Do Western scholars know, for example, that more than once the question has been asked outside Europe whether a Westerner is at all capable of studying other literatures? Perhaps they just shrug their shoulders at what seems such an impertinent question, but maybe it is pertinent after all if we ask ourselves what is behind that question. For example, in an article entitled "Comparatism and Separatism in African Literature," Isidore Okpewho from Nigeria explains that there are two camps among African scholars of comparative literature. Besides those who urge using the same broad definition mentioned here, there are others who see no merit in this sort of comparatism, since Western students of literature in the past have made it plain that they saw no merit in African literature when doing their comparative research. The same narrow vision that has plagued Western research is thus adopted as a reaction by those who feel they have been sold short by this attitude. And then there is the fact that in cases where Westerners did give attention to other literatures, they approached them from a very Eurocentric point of view. Okpewho is absolutely right when he notes that

the political undercurrents of comparatism do indeed deserve some emphasis, especially in the light of the painful political history of Africa. The colonial and other foreign presences among us did so much savagery to our cultural values that it is no surprise to find some of our scholars looking inward for a rediscovery of our violated essences. But we can also take what seems to me a deeper view of domination and argue that it is essentially an effort toward dehumanization. 14

Nonetheless, Okpewho makes a plea for inter-cultural literary research, even though he readily admits that this research is still hampered by the historical relations based on inequality that have stood in the way of inter-subjectivity, and still stand in the way because of Eurocentrism and reaction to it. I have taken part in many such discussions myself and, as a result, organized a seminar on exactly this subject for the Afrika-Studiecentrum in Leiden in 1976. The seminar examined the question of whether the same methods can be used for studying other literatures as for studying Western literature. Scholars from Africa, the United States and Europe came together for this discussion. Some of them quite correctly dismissed summarily any Western publications that tried, using Western criteria of quality, to see how far African literature has now advanced along the evolutionary line between prehistory and Western modernity. The unanimous conclusion reached was that methods themselves need not be culture-bound, providing the respective scholars are aware of the limitations that are imposed by their own historical and cultural situations. 15

Historical research on how texts from other cultures have been received by Western readers and critics and the other way around would certainly produce enlightening results. There is an interesting study by Gérard Leclerc on colonization and decolonization in anthropological research entitled Anthropologie et colonialisme. In the field of history, Roy Preiswerk and Dominique Perrot published Ethnocentrism et histoire. Mouralis' above 
mentioned book, Les Contre-Littératures, places our Western literature in a broader relative perspective. 16 There are indications of a changing approach in the human sciences. As far as the study of literature is concerned, some critical questions may be useful.

First, how do we define for ourselves the term "world literature"'? Does our definition contain any traces of cultural evolutionism? Research in the field of national literatures requires fitting them into a larger whole to illustrate the relationships between the literature in question and other literatures within the same or other cultures. Such exploration also allows us better insight into our own literature and culture.

Second, the choice of what is to be seen as literature, and the question of who does the choosing, is very significant. Historical textbooks and encyclopedias reveal the world view of the group from which they originate. It would be interesting to confront such a literary choice with a selection of what has been explicitly left out - works from the counter-literatures. This would sharpen our insight into the problem of value judgements.

Third, with respect to the writing of literary history, the question is where one has it begin. In the West it has not been at all unusual to have history start at the point at which the West began to play a role or first came into contact with the area under consideration. For the history of literature, this has often meant leaving out oral literature altogether. The criteria for assessing quality are often heavily influenced by evolutionism for Western critics. For example, according to Robert Cornevin, theatre in Africa came into existence after the coming of the Europeans to Africa. His book on the subject, Le Théâtre en Afrique noire et à Madagascar, is dedicated to a colonial Frenchman, whom he calls "the father of the African stage."17 Like the Chadwicks in the forties and C.M. Bowra in the sixties, Ruth Finnegan, in 1970 , also bases her definition of an epic on the written versions of the Iliad and the Odyssey that have reached us through the pen of Homer. The Nigerian Okpewho, himself a classicist, raises some questions about this after having carefully studied a number of the oral epics of Africa. He reproaches Finnegan

for setting Homer up as the yardstick of definition of the epic and for dismissing as inadequate all "primitive" heroic narratives which do not mimic the classic devices of Homer (or at least such of them as the written culture has passed on to us). I have indeed made the Homeric corpus the major counterpoint of my examination of various African texts and have consequently reached conclusions which raise questions about the validity of the fashionable premises concerning the art of Homer. 18

The interesting thing about African epics is that they are still passed on orally and can thus yield important data about the oral transmission of the epic. For a long time, no Western researchers had ever considered this possibility as far as the study of Homer was concerned. The African epics were ignored or neglected.

Fourth, widely varying views are held on what "literary" means. Naturally, the notion that "literary" always means the same everywhere in the world and 
can thus be pinned down in a universal definition has or has had the most followers in Eurocentric circles. Note that the term "universal" in this context turns out to be a synonym (or euphemism?) for Western. The new approach to comparative study of literature leaves ample room for studying the highly various communication situations that occur in literature as it functions in different groups, eras and cultures.

Writers in the Third World are more aware of the dangers of Eurocentrism in world culture and they have often reacted against it. One may think, for example, of a brilliant essay by a Cuban writer Alejo Carpentier, who speaks of the necessarily baroque style of Latin American literature. According to him, everyone has heard of the chestnut or walnut tree, but how many people know about the ceiba or the papaya tree? Thanks to Western literature, the Latin American knows about the pine tree in the snow, even though he has never seen one, because he has read descriptions in literary texts. However, the mother of the trees, the ceiba, has yet to be described, and the same is true for the papaya: these American trees exist and therefore have to be introduced into fiction writing. According to Carpentier, this is not easy because they do not have the good fortune of being called "pine tree" or "birch" and the French King Saint-Louis never languished in their shadows, nor did Alexander Pushkin ever dedicate a poem to them. Carpentier emphasizes that Latin American novelists must name everything that affects, surrounds and determines them, in order to place them within the universal vocabulary. This means, in his opinion, abandoning such techniques in vogue in the West as those of the French nouveau roman, for example. In Latin America, one must opt for the baroque style out of the necessity to give things names. 19

This is happening not only in Latin America, but also in other parts of the world outside Europe, and it springs from the same awareness. New perspectives on the world lead to new texts and new perspectives on literature lead to a new kind of criticism. Things are being described, named or renamed that had never before been put into written words, or had been described with (deliberate?) inaccuracy. Many oral "texts," transmitted for centuries exclusively in the oral form, are now being transcribed in the written form. On the basis of so much new material and data, it is inevitable that, at the level of research, a number of concepts and views must also be redefined or modified. The comparative study of criticism from different cultures will certainly be quite enlightening, because a different cultural background may lead to completely different interpretations of a text: well-known writers like Joseph Conrad and V.S. Naipaul are cases in point.

The main question I wanted to ask in this paper was how Western is the study of literature, how Eurocentric is literary research? This question is, of course, improper, because science, even human science, must in principle (as we teach our students) meet requirements of well-groundedness, systematics and accessibility. If this is so, the combination of "Western" and "science" is thus theoretically a contradiction in terms. In practice - partly because we know too little of other literatures and partly because we unconsciously let ourselves be influenced too much by our own value system - we make 
judgements that are indeed demonstrably Western and not as well grounded, systematic or objective as our discipline demands of us.

Let us therefore conclude with a variation on Toynbee:

The scholar, critic, student or teacher of literature ought to strive now with all his or her might to widen his or her public's literary horizon; and to do this he or she must begin by widening his or her own. 20

Free University, Netherlands

\section{NOTES}

1 René Wellek and A. Warren, Theory of Literature (1949; rpt. Harmondsworth: Penguin, 1973).

2 Haskell M. Block, Nouvelles tendances en littérature comparée (Paris: Nizet, 1970; René Etiemble, "Littérature comparée, ou Comparaison n'est pas raison," in Savoir et gout, Vol. 3 of Hygiene des lettres (Paris: Gallimard, 1958), pp. 154-74. See also René Etiemble, Essais de littérature (vraiment) générale (Paris: Gallimard, 1974), pp. 9-35.

3 Roy Harvey Pearce, Historicism Once More: Problems and Occasions for the American Scholar (Princeton: Princeton University Press, 1969); D.W. Fokkema, "Cultural Relativism en vergelijkende literatuurwetenschap," paper presented in Amsterdam, 1971.

4 Ruth Benedict, Patterns of Culture (1935; rpt. London: Routledge and Kegan Paul, 1971); Melville Herskovits, ed., Cultural Relativism: Perspectives in Cultural Pluralism (New York: Random House, Vintage, 1973). See also Ton Lemaire, Over de warrde van culturen: Een inleiding in de cultuurfilosofie. Tussen europacentrisme en relativisme (Baarn: Ambo, 1976).

5 E.B. Tylor, Primitive Culture, 2 vols. (London, 1871; rpt. New York: Harper Torch, 1958).

6 Arnold Toynbee, "Widening Our Historical Horizon," in New Movements in the Study and Teaching of History, ed. Martin Ballard (London: Temple Smith, 1970), pp. 50-62.

7 See, for example, her Oral Literature in Africa (London: Oxford University Press, 1977) and Oral Poetry: Its Nature, Significance and Social Context (Cambridge: Cambridge University Press, 1977).

8 See D.W. Fokkema, "Vergelijkende literatuurwetenschap en het nieuwe paradigma," Forum der Letteren, June 1981, pp. 179-92.

9 Pierre V. Zima, "Les Mécanismes discursifs de l'idéologie," Revue de l'Institut de sociologie, 4 (1981), 719-40.

10 Bernard Mouralis, Les Contre-Littératures (Paris: P.U.F., 1975).

11 Itamar Even-Zohar, "Polysystem Theory," Poetics Today, Nos. 1-2 (1979), p. 290.

12 Even-Zohar, p. 291.

13 Even-Zohar, p. 292.

14 Isidore Okpewho, "Comparatism and Separatism in African Literature," World Literature Today, 55, No. 1 (1981), 26.

15 See Mineke Schipper, ed., Text and Context: Methodological Explorations in the Field of African Literature (Leiden: Afrika-Studiecentrum, 1977). 